\title{
Effects of immunizing ewes against bone morphogenetic protein 15 on their responses to exogenous gonadotrophins to induce multiple ovulations
}

\author{
Jennifer L Juengel, Laurel D Quirke, Stan Lun, Derek A Heath, Peter D Johnstone \\ and Kenneth P McNatty ${ }^{1}$
}

Centre for Reproduction and Genomics, AgResearch Limited, Invermay Animal Research Centre, Puddle Alley, Private Bag 50034, Mosgiel 9053, New Zealand and ${ }^{1}$ School of Biological Sciences, Victoria University of Wellington, Wellington, New Zealand

Correspondence should be addressed to J L Juengel; Email: jenny.juengel@agresearch.co.nz

S Lun is now at Mesynthes Limited, Lower Hutt 5040, New Zealand.

$\mathrm{D}$ A Heath is now at School of Biological Sciences, Victoria University of Wellington, Wellington, New Zealand.

\begin{abstract}
Sheep with a heterozygous inactivating mutation in the bone morphogenetic protein 15 (BMP15) gene experience an increased ovulation rate during either a natural oestrous cycle or a cycle in which exogenous FSH and eCG (gonadotrophins) are given to induce multiple ovulations. The primary aim of these studies was to determine whether ewes immunised against BMP15 would also show an improved superovulation rate following exogenous gonadotrophin treatment. A secondary aim was to determine the effects of BMP15 immunisation on ovarian follicular characteristics. In most ewes (i.e. $>75 \%$ ) immunised with a BMP15-keyhole limpet haemocyanin peptide in an oil-based adjuvant in order to completely neutralise BMP15 bioactivity, there was no superovulation response to exogenous gonadotrophins. In ewes treated with exogenous gonadotrophins following a BMP15-BSA peptide immunisation in a water-based adjuvant to partially neutralise BMP15 bioactivity, the ovulation rate response was similar to the control superovulation treatment groups. Characterisation of follicular function revealed that the water-based BMP15-immunised animals had fewer non-atretic follicles 2.5-3.5 or $>4.5 \mathrm{~mm}$ in diameter compared with controls. Basal concentrations of cAMP were higher in granulosa cells from animals immunised against BMP15 than control animals. There were no significant differences in the concentrations of cAMP between granulosa cells from BMP15- and control-immunised animals when given FSH or hCG, although there were differences in the proportions of follicles in different size classes that responded to FSH or hCG. Thus, immunisation against BMP15 may have been causing premature luteinisation and thereby limiting the numbers of follicles recruited for ovulation following treatment with exogenous gonadotrophins. Reproduction (2011) 142 565-572
\end{abstract}

\section{Introduction}

The amount of functional bone morphogenetic protein 15 (BMP15) or growth differentiation factor 9 (GDF9), two related oocyte-derived growth factors, has been shown to influence ovulation rate in ewes (Galloway et al. 2000, Juengel et al. 2002, Hanrahan et al. 2004). In wild-type ewes $(++)$, the amount of BMP15 or GDF9 that was produced normally results in an ovulation rate of 1 and 2. However, in ewes that are heterozygous carriers of an inactivating mutation in BMP15 or GDF9 (Galloway et al. 2000, Hanrahan et al. 2004), the reduced amount of functional BMP15 or GDF9 results in ovulation rates of 2 and 3. By contrast, in homozygous mutant BMP15 or GDF9 ewes, which lack either active BMP15 or GDF9, no ovulations occur and the animals are sterile (Hanrahan et al. 2004, McNatty et al. 2004,
Nicol et al. 2009). Inverdale ewes, heterozygous for BMP15 mutations $(I+)$, administered exogenous FSH and eCG to produce multiple ovulations have a higher ovulation rate than ++ contemporaries, indicating an increased responsiveness to gonadotrophins (McNatty et al. 2006). Thus, if this phenotype could be mimicked in wild-type ewes, this could form the basis for an improved superovulation methodology for increasing the efficiency of generating embryos from highly valued livestock or from endangered species.

Immunisation against BMP15 or GDF9 in ++ ewes has been used to mimic the phenotypes observed during the natural reproductive cycle in ewes with mutations in BMP15 or GDF9 (Juengel et al. 2002, 2004, McNatty et al. 2007). Immunising wild-type animals with a waterbased adjuvant resulted in increased ovulation rates, 
similar to that observed in heterozygous ewes (Juengel et al. 2004). By contrast, immunising ewes with an oilbased adjuvant inhibited normal follicular growth resulting in anovulation (Juengel et al. 2002, McNatty et al. 2007), similar to what is observed in animals homozygous for the BMP15 or GDF9 mutation. However, it is currently not known whether ewes that have been immunised against BMP15 or GDF9 have an increased responsiveness to exogenous gonadotrophins. Given that the effects of exogenous FSH and eCG on ovulation rate in ewes heterozygous for GDF9 mutations are unknown, we focused on determining whether ewes immunised against BMP15 showed increased ovulation rates following exogenous gonadotrophin treatment. A secondary objective was to determine the effects of immunisation against BMP15 on characteristics of ovarian follicles including the gonadotrophin responsiveness of the granulosa cells.

\section{Results}

\section{Antibody response to immunisation}

As expected, the optical density readings following ELISA to detect antibodies against BMP15 in the BMP15BSA- and BMP15-keyhole limpet haemocyanin (KLH)immunised groups at 2 weeks following the booster immunisation had average increases that were 2.4- and 44.9-fold higher $(P<0.01)$, respectively, than the values in the preimmune samples. In addition, the optical density readings for antibodies against BMP15 in the BMP15-BSA-immunised groups at the time of tissue collection were on average 4.3 fold greater $(P<0.05)$ than in the preimmune samples. No such increases in optical density readings for the presence of antibodies against BMP15 were observed in the $\mathrm{KLH}$ - or BSA control-immunised animals (average fold value 0.9 to 1.2 compared with preimmune sample).

\section{Response to treatment to induce ovulation of multiple follicles}

In the ewes immunised with BMP15-KLH in an oil-based adjuvant, only four of 17 animals (i.e. 24\%) ovulated in response to the exogenous gonadotrophin regimen following any of the three successive treatments. Two animals responded twice (third observation was missed in one of these animals) and two others responded once each. In contrast, all KLH control animals ovulated in response to at least one treatment with exogenous gonadotrophins. The mean \pm s.E.M. ovulation rate in the $\mathrm{KLH}$ control animals was $6.5 \pm 0.7$. The range of ovulation rates observed was $0-18$. The effect of immunisation with the BMP15-KLH peptide was severe and long lasting as the majority of the animals $(13 / 16)$ failed to return to oestrus through the subsequent breeding season (i.e. 8 months after the initial immunisation). In contrast, all of the KLH-immunised control animals returned to oestrous during the subsequent breeding season. Most animals (>85\%) immunised with the BMP15-BSA or BSA regimes in the water-based adjuvant ovulated on at least one occasion to the exogenous gonadotrophin treatment: two BMP15BSA- and one of the BSA-immunised animals failed to respond to any of the gonadotrophin treatments (only two observations were made for this BSA-immunised ewe). The mean \pm S.E.M. ovulation rates following exogenous gonadotrophin treatment were not significantly different between the BMP15-BSA $(5.1 \pm 0.7)$ and the BSA treatment groups $(6.9 \pm 0.7)$. The range of ovulation rates observed was 0-15 for the BMP15-BSA treatment group and 0-14 for the BSA treatment group. All ewes immunised with BSA or BMP15-BSA antigens resumed oestrous cyclicity during the following breeding season.

\section{Characterization of ovarian follicular populations}

At 4 weeks following a booster immunisation, the distribution of follicles in the various size classes differed between the BMP15-BSA- and BSA-immunised animals (Fig. 1). Of note was the paucity of follicles $>2.5-3.5$ and $>4.5 \mathrm{~mm}$ in diameter observed in BMP15-BSA-immunised ewes. The three largest healthy follicles from the BSA group were 20-38\% larger in size compared with those in the BMP15-BSA group (Fig. 2) and the two largest had 57 and $37 \%$ more granulosa cells. No significant differences in the numbers of granulosa cells were observed in the third largest follicles for each treatment group. The differences in the number of granulosa cells were linked to the differences in the diameters of the follicles in the two treatments. No significant differences in cell numbers were detectable when follicle size was taken into account.

In the granulosa cells, the basal concentrations of cAMP were higher in animals immunised with BMP15BSA than in the BSA controls (Fig. 3). There were no differences in the levels of cAMP between BMP15-BSAand BSA-immunised animals when given $\mathrm{FSH}$ at 10, 100 and $1000 \mathrm{ng} / \mathrm{ml}$ (Fig. 3). Moreover, although the mean level of CAMP in response to $\mathrm{LH}$ was higher in the BMP15BSA-immunised animals, this only tended toward significance $(P<0.10)$ from the BSA control (Fig. 3). Approximately $50 \%$ of follicles $\leq 2.5 \mathrm{~mm}$ in diameter in both the BMP15-BSA- and the BSA control-immunised groups responded to the highest dose of FSH but most (57/61) did not respond to hCG. The proportion of follicles $>2.5 \mathrm{~mm}$ in diameter that were $\mathrm{FSH}$ responsive did not differ between treatments and was $41 \%$ in BSAimmunised and 53\% in BMP15-BSA-immunised ewes. Similarly, the proportion of follicles $>2.5 \mathrm{~mm}$ in diameter that were hCG responsive did not differ between treatments and was $18 \%$ in BSA and $24 \%$ in BMP15-BSAimmunised ewes. However, division of follicles into smaller size classes revealed that the proportion of 

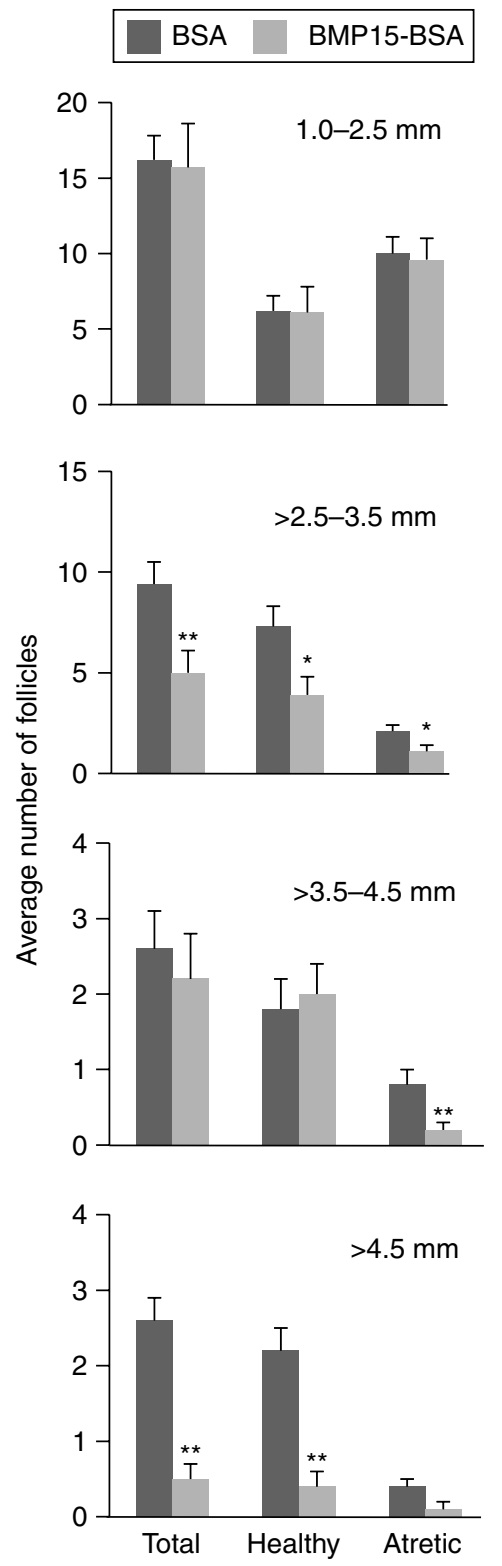

Figure 1 Average number (mean and S.E.M.) of total, healthy and atretic follicles present in each follicle size classification (i.e. diameters of $1-2.5,>2.5-3.5,>3.5-4.5$ and $>4.5 \mathrm{~mm}$ ) in ovaries collected $\sim 4$ weeks after ewes were given a booster immunisation against BSA or bone morphogenetic protein 15-BSA (BMP15-BSA). ${ }^{*} P<0.05$, ${ }^{* *} P<0.01$ compared with the BSA control within each follicle type.

follicles $>2.5-3.5 \mathrm{~mm}$ in diameter responsive to hCG was higher in the BMP15-BSA-immunised ewes (Table 1), whereas $\mathrm{FSH}$ responsiveness was higher in follicles $>3.5-4.5 \mathrm{~mm}$ in diameter in BMP15-BSA-immunised ewes compared with BSA control ewes (Table 1).

\section{Discussion}

Immunisation of ewes against BMP15 has been used to investigate the role of oocyte-derived growth factors in regulating ovulation rate. Two phenotypes have been observed: an inhibition of follicular growth and ovulation when the majority of biologically active BMP15 is neutralised and an increased ovulation rate when BMP15 is partially neutralised (Juengel et al. 2002, 2004, McNatty et al. 2007). However, the response of BMP15-immunised ewes following an exogenous gonadotrophin treatment to induce superovulation was unknown. In this study, treatment with exogenous gonadotrophins was unable to overcome the block in follicular development when ewes were immunised with a regimen designed to fully neutralise BMP15. Thus, administration of supplementary gonadotrophins, as is typically used for superovulation purposes, was unable to support normal follicular growth when little or no BMP15 was present. The effects of immunisation against BMP15-KLH antigen was long lasting as the majority of the ewes failed to demonstrate oestrous behaviour for at least 7 months after the last immunisation injection was administered. This is consistent with the BMP15-KLH immunisation affecting follicles from the earliest stages of development (Juengel et al. 2002, McNatty et al. 2007). Follicular growth in ewes without biologically active BMP15 is impaired from the primary stage of development (Braw-Tal et al. 1993). Furthermore, it is known that the gonadotrophin concentrations in ewes homozygous for an inactivating mutation in BMP15 are significantly higher than in the wild-type ewes given the lack of development of antral follicles in these ewes and thus the lack of feedback regulation of gonadotrophin synthesis and secretion (Braw-Tal et al. 1993). In primary and preantral follicles, ovarian follicular growth is thought not to be dependent on FSH or LH (Scaramuzzi et al. 1993). Nevertheless, granulosa cells in preantral follicles have receptors for FSH and the theca interna of large preantral follicles have receptors for LH (Juengel et al. 2000, Logan et al. 2002), thus the failure of the supplementary gonadotrophin treatment regimen to overcome the absence of BMP15 indicates the dominance of intraovarian growth factors during early follicular growth.

Somewhat surprisingly, though, ewes given an immunisation regimen designed to neutralise a portion of BMP15 did not respond to exogenous gonadotrophins with an increased ovulation rate relative to that in the control ewes. In fact, the BMP15-BSA-immunised ewes had lower average ovulation rates than the BSAimmunised controls, but this did not reach statistical significance. Considerably more animals would need to be examined to be able to determine whether immunisation against BMP15 would consistently suppress ovulation rate following treatment with exogenous gonadotrophins. However, it is clear that the BMP15BSA animals did not show the hypothesised increase in ovulation rate expected. The failure to respond with an increased ovulation rate was in contrast to the response observed in ewes with a heterozygous inactivating mutation in BMP15, which were found to have an 


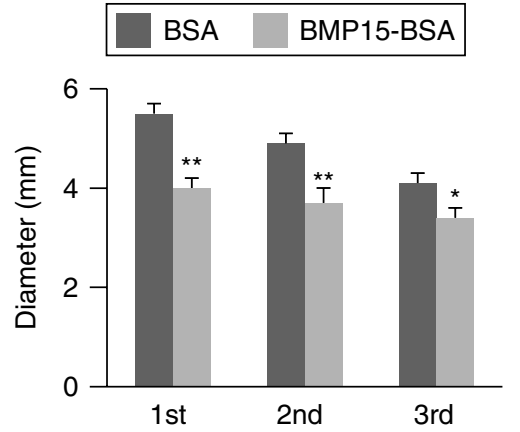

Figure 2 Average follicle size (mean and S.E.M.) for the three largest healthy follicles present in ovaries collected $\sim 4$ weeks after ewes were given a booster immunisation against BSA or bone morphogenetic protein 15-BSA (BMP15-BSA) immunisation. ${ }^{*} P<0.05,{ }^{* *} P<0.01$ compared with the BSA control within each follicle type.

increased responsiveness (i.e. a higher ovulation rate) to exogenous gonadotrophins (McNatty et al. 2006). One possible explanation for this difference could be the differing times the follicles were exposed to decreased concentrations of BMP15. However, no effect was observed across three observations of superovulation treatments spaced over 3 months. Furthermore, it is known that immunoneutralisation of BMP15 for just a few days is able to affect follicular growth indicating that BMP15 is important for both the early and the late stages of follicular growth (Juengel et al. 2002). Given that the exogenous gonadotrophin treatment mainly enhances the growth of the medium to large antral follicles (i.e. those $\geq 2 \mathrm{~mm}$ diameter; McNatty et al. 2010) over a relatively short time frame (i.e. 4-5 days), it seems unlikely that the failure to observe the increased responsiveness to $\mathrm{FSH}$ was related to a differing length of time in which the follicles were exposed to reduced concentrations of BMP15 in the immunised versus the ewes with naturally occurring mutations in BMP15.

Characterization of the follicular population of immunised ewes revealed clear differences between the BMP15-BSA-immunised animals and the BSAimmunised control animals. These included changes in the distribution of sizes of the follicles, the diameter and number of cells in the largest healthy follicles, differences in baseline cAMP production and differences in the proportions of follicles responding to $\mathrm{FSH}$ and $\mathrm{LH}$ in the different size classes. Immunisation against BMP15 reduced the number of follicles $>2.5-3.5 \mathrm{~mm}$ in diameter and those $>4.5 \mathrm{~mm}$ in diameter. A similar reduction in number of follicles $>2.5-3.5 \mathrm{~mm}$ in diameter has been observed in anoestrous I+ ewes, which are heterozygous for an inactivating mutation in BMP15 (McNatty et al. 2009). However, the reduction in follicles $>4.5 \mathrm{~mm}$ in diameter was not observed in the $\mathrm{I}+$ ewes. While the number of follicles $>4.5 \mathrm{~mm}$ in diameter were not altered in I+ ewes compared with their controls, the number of granulosa cells within these follicles was reduced. Similarly, the number of granulosa cells in the two largest healthy follicles was reduced in the BMP15-immunised ewes in the current study. However, this reduction in cell numbers was related to an overall reduction of follicular diameter. Thus, the number of granulosa cells per follicle was similar between the BMP15-immunised ewes and their respective controls when follicular diameter was taken into account. Potentially, the effects on diameter, and thereby numbers of granulosa cells, in the follicles in the animals immunised against BMP15 represent a more severe suppression of BMP15 in these animals than that observed in I+ ewes, which are predicted to have a $50 \%$ reduction in BMP15 compared with wild-type contemporaries (McNatty et al. 2004). The reduction of numbers of follicles $>4.5 \mathrm{~mm}$ in diameter, taken together with reduced diameter and granulosa cell numbers of the largest follicles observed in the BMP15BSA-immunised animals, is reminiscent of the phenotype observed in Booroola ewes (BB) homozygous for mutations in BMP receptor, type 1B (BMPR1B; Driancourt et al. 1985, McNatty et al. 1985, Souza et al. 2003). The BMPR1B has been identified as a receptor for BMP15 (Moore et al. 2003), and mutations in BMP15 and $B M P R 1 B$ interact synergistically in ewes with respect to ovulation rate during natural oestrous cycles (Davis et al. 1999, Chu et al. 2007), thus the similarity in phenotypes is not altogether surprising. Ewes homozygous for the mutation in BMPR1B have greater increases in ovulation rate than observed in I+ ewes (McNatty et al. 2004). Modelling of the potential effects of various types of mutations in BMP15 and BMPR1B supports the hypothesis that ovulation rate will increase as the amount of BMP15 bioactivity decreases until a critical minimal threshold is reached, at which time follicular growth is blocked (McNatty et al. 2004). From the modelling data,

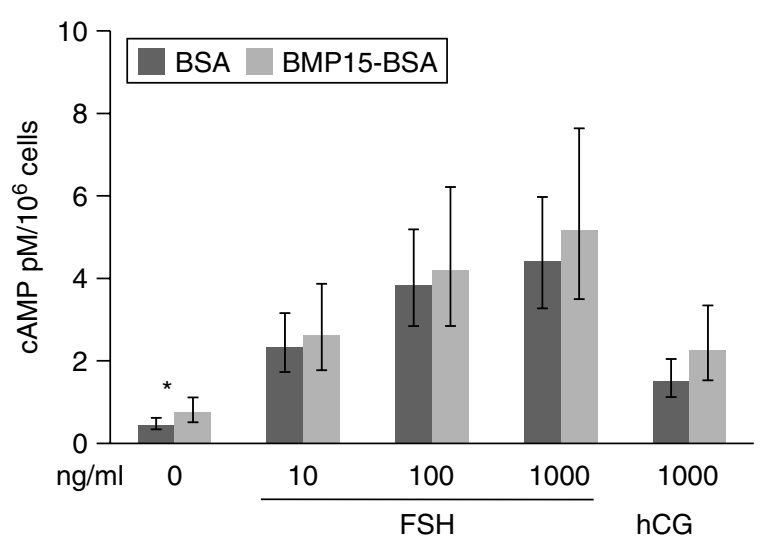

Figure 3 CAMP response (geometric mean and 95\% confidence intervals) of ovarian follicles collected $\sim 4$ weeks after ewes were given a booster immunisation against BSA or bone morphogenetic protein 15-BSA (BMP15-BSA) to different concentrations of FSH or hCG. Given that classifications of follicular diameter did not significantly affect responsiveness to either FSH or hCG, data from all sizes of follicles were combined. $* P<0.05$ compared with the BSA control within each treatment. 
Table 1 Percentage of follicles that responded to FSH or hCG in BSA- or bone morphogenetic protein 15 (BMP15)-immunized ewes.

\begin{tabular}{|c|c|c|c|c|c|c|}
\hline \multirow{2}{*}{$\begin{array}{l}\text { Follicle } \\
\text { diameter (mm) }\end{array}$} & \multicolumn{2}{|c|}{ Number of GC assays } & \multicolumn{2}{|c|}{ FSH responsive (\%) } & \multicolumn{2}{|c|}{ hCG responsive (\%) } \\
\hline & BSA & BMP15 & BSA & BMP15 & BSA & BMP15 \\
\hline$<2.5$ & 32 & 29 & 46.9 & 48.3 & 3.1 & 10.3 \\
\hline$>2.5-3.5$ & 62 & 30 & 40.3 & 46.7 & 6.4 & $26.7^{*}$ \\
\hline$>3.5-4.5$ & 24 & 24 & 29.2 & $58.3^{*}$ & 16.7 & 20.8 \\
\hline$>4.5$ & 32 & 5 & 50.0 & 60.0 & 40.6 & 20.0 \\
\hline
\end{tabular}

GC, granulosa cells. *Proportion of FSH- or hCG-responsive follicles differed between BSA- and BMP15-BSA immunized animals, $P<0.05$.

ewes homozygous for the Booroola mutation are predicted to have less BMP15 bioactivity at the granulosa cells than ewes heterozygous for a BMP15 mutation, and this is proposed to underlie the increased ovulation rate observed in BB compared with I+ ewes. BB ewes develop preovulatory follicles that are significantly smaller in diameter than in wild-type animals. Overall, the smaller diameter of the putative preovulatory follicles in the ewes immunised against BMP15 and the BB ewes are also consistent with the ewes immunised against BMP15 having less bioavailable BMP15 than those likely to be present in I+ ewes. However, since BB ewes are also more responsive to exogenous gonadotrophins than wild-type animals (McNatty et al. 2006), it seems unlikely that a reduced level of biologically active BMP15 compared with that to be expected in I+ ewes can explain the failure of the BMP15-immunised animals to have an increased superovulation rate response to exogenous gonadotrophins as has been observed in I+ ewes.

Immunisation against BMP15 altered the responsiveness of the follicles to gonadotrophins. Similar to observations in I+ ewes, there was no overall affect of immunisation against BMP15 on the responsiveness of the granulosa cells to FSH (McNatty et al. 2009). However, there tended to be an increased responsiveness to LH in the BMP15-immunised ewes, which is in agreement with the increased responsiveness observed in I+ ewes (McNatty et al. 2009). There were also significant changes in the proportions of follicles of a particular size class that responded to either $\mathrm{FSH}$ or LH. Immunisation against BMP15 resulted in a greater proportion of follicles $>3.5-4.5 \mathrm{~mm}$ in diameter with granulosa cells that produced cAMP in response to FSH. This was not previously observed in I+ ewes (McNatty et al. 2009) and is likely the result of the smaller overall size range of the maturing follicles in the BMP15immunised animals. The increased proportion of follicles responding to hCG, as a surrogate for $\mathrm{LH}$, in follicles >2.5-3.5 mm in diameter in the BMP15immunised ewes was similar to that for similar-sized follicles in the I+ ewes (McNatty et al. 2009).

An important finding was that the baseline concentrations of cAMP were also increased in the BMP15-immunised ewes compared with that in the BSA-immunised controls. The increase in basal concentrations of CAMP was not previously observed I+ ewes
(Shackell et al. 1993, McNatty et al. 2009), and this may have contributed to the failure to observe an increased superovulation response to exogenous gonadotrophins in the immunised ewes. It is possible that elevated basal cAMP leads to premature luteinisation and prevention of some follicles from obtaining a preovulatory LH response. The lack of increase in the proportion of follicles that responded to hCG in the $>3.5-4.5 \mathrm{~mm}$ diameter follicles, even though there was an increase in the proportion of follicles that responded to $\mathrm{FSH}$, in the BMP15-immunised ewes is not inconsistent with this hypothesis. Future studies to determine the effect of immunisation against BMP15 on oestradiol and progesterone synthesis would provide additional insights into the potential premature luteinisation of the granulosa cells in BMP15-immunised ewes.

Sustained, albeit high, concentration of cAMP in primary rat granulosa cells was also associated with increased apoptosis (Aharoni et al. 1995). Thus, it is possible that the increased basal CAMP concentrations in the BMP15-immunised ewe results in increased follicular loss and thus a reduced pool of follicles to be recruited for ovulation by exogenous FSH. While I+ ewes have increased number of follicles $1 \mathrm{~mm}$ in diameter or greater than their wild-type contemporaries (Shackell et al. 1993), the BMP15-immunised animals did not have a similar increase in follicle numbers. In fact, total number of follicles tended $(P<0.1)$ to be reduced in the BMP15-immunised ewes when compared with the BSA control ewes. Thus, a reduced pool of follicles for recruitment for superovulation is likely to have occurred and this might have been driven by increased basal levels of cAMP.

The effects of immunisation against BMP15 on other members of the transforming growth factor $\beta$ (TGFB) superfamily or the signalling pathways were not tested in the current study. However, the peptide used does not show sequence homology with other TGFB family members and it is known that ewes immunised with the BMP15 peptide utilised in this study do not show any cross-reaction with GDF9, the family member most closely related to BMP15 (McNatty et al. 2007). Thus, the effects of the immunisation would be limited to neutralisation of BMP15 rather than neutralisation of another family member. Whether immunisation with BMP15 would affect expression of any other family 
member or its signalling pathway is unknown. BMP15 has been shown to signal through BMPR1B (Moore et al. 2003) and BMPR2 (Moore et al. 2003, Edwards et al. 2008) and the sheep follicle produces several BMPs (Campbell et al. 2006, Fabre et al. 2006, Juengel et al. 2006). In sheep, several ovarian cell types express the receptors for BMP15 as well as other members of the BMP family (Souza et al. 2002, Juengel \& McNatty 2005) and thus, if altered concentrations of biologically available BMP15 altered expression of the receptors or signalling molecules, an indirect effect, through alterations of other members of the BMP family, could occur. It is currently not known whether reducing biologically active BMP15 through inactivating mutations, as occurs in heterozygous Inverdale ewes, alters the expression levels of other BMP family members or their receptors. However, expression patterns for other TGFB superfamily ligands or receptors are altered in sheep lines with mutations known to interact with the TGFB superfamily members. This includes reduced expression for BMP15 in ewes homozygous for mutations in $B M P R 1 B$ (Crawford et al. 2011). In addition, ewes heterozygous for the Woodlands gene, which is known to interact synergistically with the Inverdale and Booroola mutations (Davis et al. 2008), also showed altered expression of BMP15 as well as TGFBR 1 and BMPR $1 B$ (Feary et al. 2007). Further studies comparing the effects on decreasing biologically available BMP15 through genetic mutations (i.e. in I+ ewes) with those decreased through immunisation may provide additional insights into the differences in responsiveness to exogenous gonadotrophin.

In summary, animals immunised against BMP15 did not show a greater superovulation response to exogenous gonadotrophins compared with that in the BSAimmunised animals. This is in contrast to the increased superovulation rate response in I+ ewes. Characterization of the follicular populations in the immunised animals suggests that the reduced BMP15 bioactivity may have been causing elevated cAMP concentrations, premature luteinisation preventing some follicles gaining an ovulatory $\mathrm{LH}$ response and an increase in follicular atresia. Consequently, this may have limited the numbers of follicles recruited for ovulation during the superovulation treatment.

\section{Materials and Methods}

The experiment was approved by an internal AgResearch Animal Ethics Committee and conforms to the 1999 Animal Protection (Codes of Ethical Conduct) Regulations of New Zealand. All animals had access to pasture and water ad libitum. Unless otherwise indicated, reagents were purchased from Thermo Fisher Scientific New Zealand Ltd (Christchurch, New Zealand) or Sigma-Aldrich.

\section{Experimental design}

Wild-type ewes (Ovis aries, Romney, mixed age mature ewes, average weight of $65.3 \pm 0.8 \mathrm{~kg}$ ) were immunised with a single injection of BMP15 peptide (QAGSIASEVPGPSRC; Global Peptide Breakthrough, Fort Collins, CO, USA) conjugated to BSA (ImmunoChemical Products Ltd, Auckland, New Zealand; BMP15-BSA-immunised group; $n=15)$ or BMP15-KLH $(n=17)$ or BSA $(n=17)$ or $\mathrm{KLH}(n=17)$ for their respective control groups. A water-based adjuvant (5\% DEAE-dextran) was used in ewes immunised with the BSA-based vaccines whereas an oil-based adjuvant (Freund's complete) was used for the $\mathrm{KLH}$-based vaccines with all animals receiving $0.4 \mathrm{mg}$ antigen for the initial immunisation. This was followed by a booster (0.2 mg of antigen) 4 weeks later in 5\% DEAE-dextran adjuvant for the BSA-based vaccines or Span-Tween-Marcol adjuvant for the KLH-based vaccines as described previously (Juengel et al. 2002, 2004, McNatty et al. 2007). Immunisation against the BMP15 peptide chosen has previously been shown to generate antibodies capable of neutralizing BMP15 in vivo and in vitro (McNatty et al. 2007). In addition, this region of the protein is not highly conserved in members of the TGFB superfamily and previous studies have shown that there was no cross-reaction with GDF9, the family member most closely related to BMP15, in ewes immunised with this peptide (McNatty et al. 2007). The KLH-based vaccine in the oil-based adjuvant regimen was designed to provide a high antibody titre to neutralise the majority of BMP15 whereas the BSA-based vaccine in the water adjuvant regimen was designed to provide a lower antibody titre to neutralise a proportion of the BMP15. Two weeks after the booster immunisation, all groups were subjected to three rounds of a regimen to induce ovulation of multiple follicles, 1 month apart as described (Smith et al. 1996). Briefly, CIDRs were used to administer progesterone for 13 days (Eazi-breed CIDR sheep \& goat insert, Pfizer Animal Health, Auckland, New Zealand), and eCG was given on the morning of day 10 (300 IU; Folligon; Intervet/Schering-Plough Animal Health; Upper Hutt, New Zealand). Beginning on the morning of day 10, ovine FSH (Ovagen, ICPbio, $0.9 \mathrm{mg}$ NIADDK-oFSH-17 biopotency) was given twice daily (at $\sim 0800$ and $1600 \mathrm{~h}$ ) for 4 days. All treatments were administered during spring/early summer, when the ewes are normally seasonally anoestrus. Ovulation rate was observed by laparoscopy $\sim 5$ days after the expected day of oestrus. The ability of the animals to undergo reproductive cycles during the following breeding season (i.e. 4-8 months after initial immunisation) was monitored by noting marking by a harnessed vasectomised ram. Ovaries from the BMP15-BSA $(n=13)$ and the BSA groups $(n=17)$ were collected $\sim 4$ weeks following a further immunisation in a DEAE-dextran adjuvant, $\sim 12$ months after the first immunisation. Ovarian follicles $(>1 \mathrm{~mm}$ diameter $)$ from these animals were isolated and follicle numbers were recorded. Granulosa cells were isolated and their responses to gonadotrophins, as measured by cAMP production, were determined. The ovaries from the BMP15-KLH- and KLH control-immunised animals were not used to study ovarian follicular characteristics given the severity of the response of the animals immunised with the BMP15-KLH antigen, 
which were noted to have few ovarian follicles visible on the surface of the ovary, consistent with previous observations (Juengel et al. 2002).

\section{Determination of antibody titres}

The responses to the immunisations were determined by ELISA by assessing antibody titres before immunisation, at 2 weeks after the first booster immunisation and again at time of tissue collection using previously validated methods (Juengel et al. 2002). Serum samples from the BMP15-KLH- and KLHimmunised animals were diluted 1:10000 whereas those from BMP15-BSA- and BSA-immunised animals were diluted 1:1000. The secondary antibody dilution was 1:5000.

\section{Determination of $\mathrm{CAMP}$ responsiveness}

All ovarian follicles $>1 \mathrm{~mm}$ diameter were dissected in DMEM with $20 \mathrm{mM}$ Hepes buffer, $0.2 \mathrm{mM}$ 3-isobutyl-methylxanthine and $0.1 \%(\mathrm{w} / \mathrm{v})$ BSA. Follicles were classified as either healthy or atretic as described (McNatty et al. 1986, 2009). Determination of responsiveness of granulosa cells to gonadotrophins was undertaken only in healthy follicles. Granulosa cells from some follicles from the same animal were pooled to provide sufficient numbers of cells or to limit the number of bioassays undertaken on 1 day for logistical reasons. In these instances, the average diameter of the follicles included in the pool was used to determine the follicular classification of the pool of cells. The bioassay for determining responsiveness to FSH and $\mathrm{LH}$ was undertaken as described (McNatty et al. 2009). Concentrations of FSH tested were 10, 100 and $1000 \mathrm{ng} / \mathrm{ml}$ whereas $\mathrm{LH}$ responsiveness was tested by addition of $1000 \mathrm{ng} / \mathrm{ml}$ of hCG. The FSH preparation was prepared in house, was $>90 \%$ pure and its bioactivity was $1.4 \times$ that of USDA-oFSH-19-SIAFP RP2 and LH contamination was $<0.002 \%$ as determined by bioassay. The hCG used was CR121 with bioactivity of $13450 \mathrm{IU} / \mathrm{mg}$ (NICHD, Bethesda, MD, USA). The concentrations of cAMP were determined by RIA as described (McNatty et al. 2009). The detection limit of the assay was $0.2 \mathrm{pmol} / \mathrm{million}$ cells and the both intra- and inter-assay coefficients of variation were $<10 \%$.

\section{Statistical analyses}

Antibody titres before and after immunisation were compared using a paired Student's t-test. As the majority of the BMP15$\mathrm{KLH}$-immunised ewes failed to respond to the protocol to induce multiple ovulations, further statistical analyses were limited to comparison of the BMP15-BSA and BSA groups. As there were no significant differences in ovulation rate over the three successive laparoscopy observations within each group, an average ovulation response was calculated for each animal. Ovulation rate differences were compared using a Student's $t$-test. The average number of total, healthy and atretic follicles, the size of the three largest follicles and the number of granulosa cells in the three largest follicles were compared with Student's $t$-test. Responsiveness to FSH and hCG was compared with ANOVA with differences between individual means compared with an F-test. Values were Ln transformed prior to analyses. Data presented are the back-transformed values from the calculated Ln means. Initial analyses indicated that the classifications of follicular diameter did not significantly affect responsiveness to either FSH or hCG; therefore, all follicular classes were combined. A secondary analysis was undertaken examining the proportion of follicles considered to have responded to the highest dose of $\mathrm{FSH}$ or hCG as previous studies have shown that an early responsiveness to hCG was observed in I+ animals (McNatty et al. 2009). Response was defined as the production of $>5 \mathrm{pmol} / \mathrm{million}$ cells of cAMP (McNatty et al. 2009). Differences between the proportion of granulosa cell pools responding in the BMP15-BSA group and the BSA control group were compared using $\chi^{2}$ analyses.

\section{Declaration of interest}

AgResearch holds patents related to the use of BMP15 in regulating ovarian function. J Juengel and $\mathrm{K}$ McNatty are listed as inventors on these patents; however, both have assigned their ownership to AgResearch Ltd.

\section{Funding}

Funding support was received from the New Zealand Ministry of Science and Innovation, New Zealand (grant number: C10X0810).

\section{Acknowledgements}

We wish to thank Dr Lloyd Moore (AgResearch) for the purified ovine FSH and the National Institute of Child Health and Development (Bethesda, USA) for the hCG. We also thank Dan Olliver for assistance with the animal work.

\section{References}

Aharoni D, Dantes A, Oren M \& Amsterdam A 1995 cAMP-mediated signals as determinants for apoptosis in primary granulosa cells. Experimental Cell Research 218 271-282. (doi:10.1006/excr.1995. 1156)

Braw-Tal R, McNatty KP, Smith P, Heath DA, Hudson NL, Phillips DJ, McLeod BJ \& Davis GH 1993 Ovaries of ewes homozygous for the X-linked Inverdale gene (FecXI) are devoid of secondary and tertiary follicles but contain many abnormal structures. Biology of Reproduction 49 895-907. (doi:10.1095/biolreprod49.5.895)

Campbell BK, Souza CJ, Skinner AJ, Webb R \& Baird DT 2006 Enhanced response of granulosa and theca cells from sheep carriers of the FecB mutation in vitro to gonadotropins and bone morphogenic protein-2, -4, and -6. Endocrinology 147 1608-1620. (doi:10.1210/en.2005-0604)

Chu MX, Liu ZH, Jiao CL, He YQ, Fang L, Ye SC, Chen GH \& Wang JY 2007 Mutations in BMPR-IB and BMP-15 genes are associated with litter size in small tailed han sheep (Ovis aries). Journal of Animal Science $\mathbf{8 5}$ 598-603. (doi:10.2527/jas.2006-324)

Crawford JL, Heath DA, Reader KL, Quirke L, Hudson NL, Juengel JL \& McNatty KP 2011 Oocytes in sheep homozygous for a mutation in bone morphogenetic protein receptor 1B express lower mRNA levels of bone morphogenetic protein 15 but not growth differentiation factor 9 . Reproduction 142 153-161. (doi:10.1530/REP-10-0485)

Davis GH, Dodds KG \& Bruce GD 1999 Combined effect of the inverdale and booroola prolificacy genes on ovulation rate in sheep. Proceedings of Association for the Advancement of Animal Breeding and Genetics $1374-77$. 
Davis GH, Galloway SM, O'Connell A, Farquhar PA, McNatty KP \& Juengel JL 2008 Hyper-prolific ewes carrying copies of three major genes: a model for studying genes controlling ovulation rate. Biology of Reproduction 78 (Supplement 1) 110. Abstract 244.

Driancourt MA, Cahill LP \& Bindon BM 1985 Ovarian follicular populations and preovulatory enlargement in Booroola and control Merino ewes. Journal of Reproduction and Fertility 73 93-107. (doi:10. 1530/jrf.0.0730093)

Edwards SJ, Reader KL, Lun S, Western A, Lawrence S, McNatty KP \& Juengel JL 2008 The cooperative effect of growth and differentiation factor-9 and bone morphogenetic protein (BMP)-15 on granulosa cell function is modulated primarily through BMP receptor II. Endocrinology 149 1026-1030. (doi:10.1210/en.2007-1328)

Fabre S, Pierre A, Mulsant P, Bodin L, DiPasquale E, Persani L, Monget P \& Monniaux D 2006 Regulation of ovulation rate in mammals: contribution of sheep genetic models. Reproductive Biology and Endocrinology 4 20. (doi:10.1186/1477-7827-4-20)

Feary ES, Juengel JL, Smith P, French MC, O'Connell AR, Lawrence SB, Galloway SM, Davis GH \& McNatty KP 2007 Patterns of expression of messenger RNAs encoding GDF9, BMP15, TGFBR1, BMPR1B, and BMPR2 during follicular development and characterization of ovarian follicular populations in ewes carrying the Woodlands FecX2W mutation. Biology of Reproduction 77 990-998. (doi:10.1095/biolreprod.107.062752)

Galloway SM, McNatty KP, Cambridge LM, Laitinen MP, Juengel JL, Jokiranta TS, McLaren RJ, Luiro K, Dodds KG, Montgomery GW et al. 2000 Mutations in an oocyte-derived growth factor gene (BMP15) cause increased ovulation rate and infertility in a dosage-sensitive manner. Nature Genetics 25 279-283. (doi:10.1038/77033)

Hanrahan JP, Gregan SM, Mulsant P, Mullen M, Davis GH, Powell R \& Galloway SM 2004 Mutations in the genes for oocyte-derived growth factors GDF9 and BMP15 are associated with both increased ovulation rate and sterility in Cambridge and Belclare sheep (Ovis aries). Biology of Reproduction 70 900-909. (doi:10.1095/biolreprod.103.023093)

Juengel JL \& McNatty KP 2005 The role of proteins of the transforming growth factor-beta superfamily in the intraovarian regulation of follicular development. Human Reproduction Update 11 143-160.

Juengel JL, Quirke LD, Tisdall DJ, Smith P, Hudson NL \& McNatty KP 2000 Gene expression in abnormal ovarian structures of ewes homozygous for the inverdale prolificacy gene. Biology of Reproduction 62 1467-1478. (doi:10.1095/biolreprod62.6.1467)

Juengel JL, Hudson NL, Heath DA, Smith P, Reader KL, Lawrence SB, O'Connell AR, Laitinen MP, Cranfield M, Groome NP et al. 2002 Growth differentiation factor 9 and bone morphogenetic protein 15 are essential for ovarian follicular development in sheep. Biology of Reproduction 67 1777-1789. (doi:10.1095/biolreprod.102.007146)

Juengel JL, Hudson NL, Whiting L \& McNatty KP 2004 Effects of immunization against bone morphogenetic protein 15 and growth differentiation factor 9 on ovulation rate, fertilization, and pregnancy in ewes. Biology of Reproduction 70 557-561. (doi:10.1095/biolreprod. 103.023333)

Juengel JL, Reader KL, Bibby AH, Lun S, Ross I, Haydon LJ \& McNatty KP 2006 The role of bone morphogenetic proteins 2, 4, 6 and 7 during ovarian follicular development in sheep: contrast to rat. Reproduction 131 501-513. (doi:10.1530/rep.1.00958)

Logan KA, Juengel JL \& McNatty KP 2002 Onset of steroidogenic enzyme gene expression during ovarian follicular development in sheep. Biology of Reproduction 66 906-916. (doi:10.1095/biolreprod66.4.906)

McNatty KP, Henderson KM, Lun S, Heath DA, Ball K, Hudson NL, Fannin J, Gibb M, Kieboom LE \& Smith P 1985 Ovarian activity in Booroola X Romney ewes which have a major gene influencing their ovulation rate. Journal of Reproduction and Fertility 73 109-120. (doi:10. 1530/jrf.0.0730109)

McNatty KP, Lun S, Heath DA, Ball K, Smith P, Hudson NL, McDiarmid J, Gibb M \& Henderson KM 1986 Differences in ovarian activity between Booroola $\mathrm{X}$ merino ewes which were homozygous, heterozygous and non-carriers of a major gene influencing their ovulation rate. Journal of Reproduction and Fertility 77 193-205. (doi:10.1530/jrf.0.0770193)

McNatty KP, Moore LG, Hudson NL, Quirke LD, Lawrence SB, Reader K, Hanrahan JP, Smith P, Groome NP, Laitinen M et al. 2004 The oocyte and its role in regulating ovulation rate: a new paradigm in reproductive biology. Reproduction 128 379-386. (doi:10.1530/rep.1.00280)

McNatty KP, Hudson N, Smith P \& Juengel JL 2006 The effects of superovulating sheep with mutations in either the activin-like kinase (Alk6) or bone morphogenetic protein (BMP15) genes on ovulation rate and embryo production. Journal of Reproduction and Development $\mathbf{5 2}$ S39-S43.

McNatty KP, Hudson NL, Whiting L, Reader KL, Lun S, Western A, Heath DA, Smith P, Moore LG \& Juengel JL 2007 The effects of immunizing sheep with different BMP15 or GDF9 peptide sequences on ovarian follicular activity and ovulation rate. Biology of Reproduction $\mathbf{7 6}$ 552-560. (doi:10.1095/biolreprod.106.054361)

McNatty KP, Heath DA, Hudson NL, Lun S, Juengel JL \& Moore LG 2009 Gonadotrophin-responsiveness of granulosa cells from bone morphogenetic protein 15 heterozygous mutant sheep. Reproduction 138 545-551. (doi:10.1530/REP-09-0154)

McNatty KP, Heath DA, Hudson NL, Reader KL, Quirke L, Lun S \& Juengel JL 2010 The conflict between hierarchical ovarian follicular development and superovulation treatment. Reproduction 140 287-294. (doi:10.1530/REP-10-0165)

Moore RK, Otsuka F \& Shimasaki S 2003 Molecular basis of bone morphogenetic protein-15 signaling in granulosa cells. Journal of Biological Chemistry 278 304-310. (doi:10.1074/jbc.M207362200)

Nicol L, Bishop SC, Pong-Wong R, Bendixen C, Holm LE, Rhind SM \& McNeilly AS 2009 Homozygosity for a single base-pair mutation in the oocyte-specific GDF9 gene results in sterility in Thoka sheep. Reproduction 138 921-933. (doi:10.1530/REP-09-0193)

Scaramuzzi RJ, Adams NR, Baird DT, Campbell BK, Downing JA, Findlay JK, Henderson KM, Martin GB, McNatty KP, McNeilly AS et al. $1993 \mathrm{~A}$ model for follicle selection and the determination of ovulation rate in the ewe. Reproduction, Fertility, and Development $\mathbf{5}$ 459-478. (doi:10.1071/RD9930459)

Shackell GH, Hudson NL, Heath DA, Lun S, Shaw L, Condell L, Blay LR \& McNatty KP 1993 Plasma gonadotropin concentrations and ovarian characteristics in Inverdale ewes that are heterozygous for a major gene (FecX1) on the $\mathrm{X}$ chromosome that influences ovulation rate. Biology of Reproduction 48 1150-1156. (doi:10.1095/biolreprod48.5. 1150)

Smith P, Hudson NL, Corrigan KA, Shaw L, Smith T, Phillips DJ \& McNatty KP 1996 Effects of the Booroola gene ( $\mathrm{FecB}(\mathrm{B}))$ on bodymass, testis development and hormone concentrations during fetal life. Journal of Reproduction and Fertility 108 253-261. (doi:10.1530/jrf.0. 1080253)

Souza CJ, Campbell BK, McNeilly AS \& Baird DT 2002 Effect of bone morphogenetic protein 2 (BMP2) on oestradiol and inhibin A production by sheep granulosa cells, and localization of BMP receptors in the ovary by immunohistochemistry. Reproduction 123 363-369. (doi:10.1530/ rep.0.1230363)

Souza CJ, Campbell BK, McNeilly AS \& Baird DT 2003 Bone morphogenetic proteins and folliculogenesis: lessons from the Booroola mutation. Reproduction Supplement 61 361-370.

Received 18 April 2011

First decision 17 May 2011

Revised manuscript received 22 June 2011

Accepted 20 July 2011 